\title{
TRENDS IN PHYSIOTHERAPY RESEARCH IN SOUTH AFRICA 1980-1989
}

\section{J Mitchell}

\section{SUMMARY}

A survey of the main papers published in the South African Journal of Physiotherapy over the past 10 years (1980 to 1989) was conducted to establish the trends in research methodology, subject topic and qualifications of the first authors. It was found that there is a significant increase in the number of experimental trials used and a similar decrease in the number of surveys conducted from the first to the second five-year periods (1980 to 1984 and 1985 to 1989 ). Statistical analyses of data were more often used in the second period. There is a marked increase in the number of articles on education/administration in the second period. In this period from 1985 to 1989 , there are fewer first authors with a Diploma in Physiotherapy only, a medical degree or a technical qualification, while there are more first authors with postgraduate qualifications. These findings support the observation that there is a growing awareness of the need for a more scientific approach to Physiotherapy research.

\section{INTRODUCTION}

A survey of articles published in the South African Journal of Physiotherapy between the years 1984 and $1989^{1}$ suggests a need for more experimental and clinical trials in the field of physiotherapy in South Africa. A survey of papers published between 1973 and 1982 in Physiotherapy Canada ${ }^{2}$ found an increase in more scientifically orientated research over this time period, which suggested "a growing commitment to research" ( $p$ 158) in Canada.

To establish whether a similar trend is occurring in physiotherapy in South Africa, a survey of all major articles published over the ten years between 1980 and 1989 in the South African Journal of Physiotherapy was carried out. An emphasis was placed on trends in research methodology, subject topic and the qualifications of the first author. The findings of this survey are reported in this paper.

\section{METHOD}

The ten years between 1980 and 1989 under review were divided into two five-year periods: 1980 to 1984 and 1985 to 1989. The major papers published in the South African Journal of Physiotherapy during these periods were studied to establish the following:-

\section{Research methodology}

This was classified as descriptive (D) if the article was principally a description of a technique, case study or basic principles. A clinical trial (C) involved a comparison of therapeutic modalities or a study of some aspect of treatment in the clinical situation. Alternatively, an experimental trial (E) was one carried out under specific scientific experimental control. A paper reporting a review or a retrospective study, with or without the use of a questionnaire, was classed as a survey (S). Note was made too of the use of statistical analyses of data.

\section{OPSOMMING}

'n Opname studie van die vernaamste artikels wat oor die laaste 10 jaar (1980-1990) gepubliseer is in die SA Tydskrif Fisioterapie om neigings in die metodes van ondersoek, onderwerpe asook die kwalifikasies van die eerste outeurs te bepaal. Daar is ' $n$ betekenisvolle verhoging in die gebruik van eksperimentele proefnemings en 'n soortgelyke daling in die aantal opname studies vanaf die eerste tot die tweede vyfjaar periodes (1980-1984 en 1985-1989). Daar is meer gebruik gemaak van statistiese evaluering in die tweede periode. Daar is meer artikels met betrekking tot onderwys/administrasie in die tweede periode. Tussen 1985-1989 was daar minder eerste outeurs met slegs 'n diploma in Fisioterapie, 'n mediese graad of tegniese kwalifikasie en wel meer eerste outeurs met nagraadse kwalifikasies. Hierdie bevindings ondersteun die waarneming dat navorsing in Fisioterapie meer wetenskaplik moet geskied.

\section{Subject topic}

The subject topics covered by each article were grouped into the following categories:-

- $\quad$ applied basic science eg anatomy (Apl)

- cardiopulmonary system/therapy (C-P)

- education/administration (Ed)

- electrotherapy/equipment (E-Q)

- geriatric factors/therapy (G)

- musculoskeletal system/therapy (M-S)

- neurological system/therapy (N)

- paediatric factors/therapy (P)

- $\quad$ psycho-social factors (P-S)

- other eg community/industrial/occupational factors/therapy (O)

\section{Authorship} follows:-

The qualifications of the first author only were recorded as

- physiotherapy, diploma (PT (Dip))

- $\quad$ physiotherapy, Bachelor's degree (PT B))

- $\quad$ physiotherapy plus another Bachelor's degree $(\mathrm{PT}+\mathrm{B})$

- physiotherapy plus an Honours/Master's degree (PT + $\mathrm{H} / \mathrm{M}$ )

- physiotherapy plus a Doctorate of Philosophy (PT + PhD)

- medical doctor (MBBCh)

- $\quad$ any other graduate (Grad)

- $\quad$ any other postgraduate (Postgrad)

- non-degree eg other diploma (Nondeg)

- $\quad$ qualification not specified (NS)

The analyses of the papers published in each five-year period were compared to establish the trends in research methodology, subject topic and authorship. 


\section{INFRARED LASER LSI 2030}

A unique module system with the latest attachment now available.

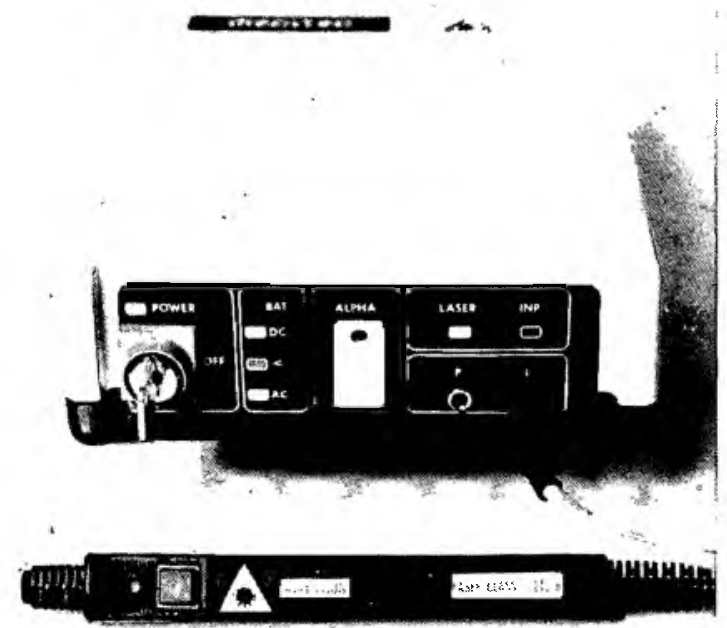

* Automatic Pointsearcher \& Electrode.

* FLÄ 09 Laser-Shower for Surface treatment (raying area of $90 \mathrm{~mm}^{2}$, 1-6 mW adjustable)

* LED Applicator (red light stimulation). * Dental Applicator with 2 Fibreoptics. * Timer.

The LSI 2030 with the Polyfrequenz-spectrum and Alphafrequenz is world wide used in medicine for all needs.

Technical Data:

$785 \mathrm{~nm} \quad$ Power supply 220V/110V

$4 \mathrm{~mW}(1-7 \mathrm{~mW})$ or with maintenance free rechargeable battery Unit is specially designed for EASY handling.

Please contact: LASER-CDSMEDTECH C.C.

Sole Agents:

Laser Equipment for Cosmetic and Medical Treatment 63 Westwoldway Parkwood 2193 Johannesburg S.A. Tel: 442-7578

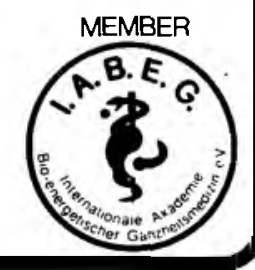

\section{BACKING UP YOUR PROFESSIONALISM}

\section{PHYSIODYN - M}

- Interferential therapy system (0 to $250 \mathrm{~Hz})$

- Four sizes pad electrodes available

- Classical 4 electrode I.F. treatment

- Bipolar electrode applications

- Compact, modern and lightweight

- German quality at budget prices

- Premodulated A.M.F. current

\section{PHYSIODYN - V}

- Suction electrode system add-on to ' $M$ '

- Continuous suction, fully

adjustable

- Pulsed suction

- Four suction cups, tubes and sponges included

- Front mounted water trap, easily visible

- Silent, smooth operation

- Easily connected to other makes of interferential equipment

\section{INTERFERENTIAL THERAPY SYSTEM}

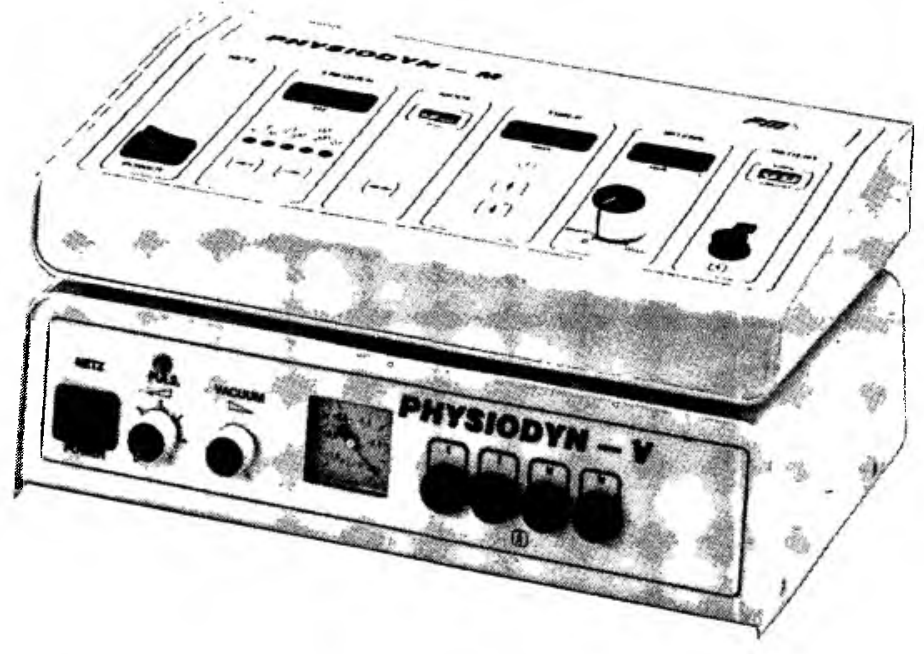

Why pay more when you can get the best at unbelievable prices?
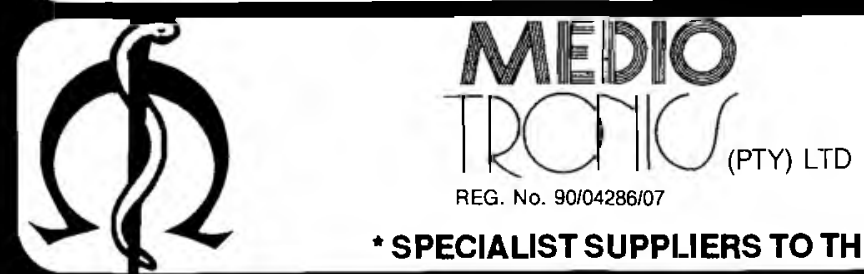

REG. No. 90/04286/07

P.O. BOX 4736, RIVONIA 2128

PHONE: (011) 803-9320/1/2/3 FAX: (011) 803-7085

* SPECIALIST SUPPIIERS TO THE PHYSIOTHERAPY PROFESSION 


\section{RESULTS}

Trend in research methodology (Table I)

\begin{tabular}{|c|c|c|c|c|}
\hline \multicolumn{5}{|c|}{ TABLE 1: TREND IN RESEARCH METHODOLOGY } \\
\hline \multirow{2}{*}{$\begin{array}{c}\text { Research } \\
\text { Methodology }\end{array}$} & \multicolumn{2}{|c|}{$1980-1884$} & \multicolumn{2}{|c|}{$1985-\overline{1989}$} \\
\hline & $n$ & $\%$ & $\mathrm{n}$ & $\%$ \\
\hline D & 58 & 71 & 53 & 69 \\
\hline $\mathrm{C}$ & 6 & 7 & 6 & 8 \\
\hline E & 6 & 7 & 12 & $\overline{16}$ \\
\hline S & 12 & 156 & 6 & 8 \\
\hline ST & 5 & 6 & 10 & 13 \\
\hline $\begin{array}{l}\text { Key } \\
\mathrm{D}=\text { Descriptive ie descrip- } \\
\text { ion of a lechnique, case } \\
\text { study of basic principles }\end{array}$ & $\begin{array}{l}\text { C = Clini } \\
\mathrm{E}=\text { Eupe } \\
\text { S = Surve } \\
\text { ST = Use } \\
\text { lysis }\end{array}$ & $\begin{array}{l}\text { al trial } \\
\text { istical ana- }\end{array}$ & $\begin{array}{l}\text { Note: } \\
\text { N }(1980 \\
\text { N }(1985\end{array}$ & $\begin{array}{l}=82 \\
=77\end{array}$ \\
\hline
\end{tabular}

The most obvious trend over the years from 1980 to 1984 and from 1985 to 1989 was the significant increase in the number of experimental trials reported (7\% to $16 \%$ of papers). The number of surveys decreased similarly from $15 \%$ to $8 \%$, but the number of descriptive papers decreased by only $2(71 \%$ to $69 \%)$. However, a marked increase in the use of statistical analyses of data (6\% to 13\%) was evident.

\section{Trend in subject topic}

\begin{tabular}{|c|c|c|c|c|}
\hline \multicolumn{5}{|c|}{ TABLE II: TREND IN SUBJECT TOPIC } \\
\hline \multirow{2}{*}{ Subject } & \multicolumn{2}{|c|}{$1980-1984$} & \multicolumn{2}{|c|}{$1985-1989$} \\
\hline & $n$ & $\%$ & $\mathrm{n}$ & $\%$ \\
\hline Apl & 6 & 7 & 2 & 3 \\
\hline C.P & 7 & 9 & 13 & 17 \\
\hline Ed & 7 & 9 & 16 & 21 \\
\hline E-Q & 7 & 9 & 5 & 7 \\
\hline $\mathbf{G}$ & 9 & 11 & 2 & 3 \\
\hline M-S & 12 & 15 & 12 & 16 \\
\hline $\mathbf{N}$ & 8 & 10 & 8 & 10 \\
\hline$P$ & 12 & 15 & 8 & 10 \\
\hline P-S & 7 & 9 & 4 & 5 \\
\hline 0 & 7 & 9 & 7 & 9 \\
\hline $\begin{array}{l}\mathrm{Key} \\
\text { Apl }=\text { Applied basic science eg } \\
\text { Anatomy } \\
\mathrm{C}-\mathrm{P}=\text { Cardiopulmonary sys- } \\
\text { tem/therapy } \\
\mathrm{Ed}=\text { Education/Administra- } \\
\text { tion } \\
\mathrm{E}-\mathrm{Q}=\text { = Electrotherapy/Equip- }\end{array}$ & $\begin{array}{l}\text { ment } \\
G=\text { Geriat } \\
M-S=M \\
\text { tem/Thera } \\
N=N e \\
\text { tem/Thera } \\
P=\text { Paed } \\
\text { apy }\end{array}$ & $\begin{array}{l}\text { ors/Therapy } \\
\text { keletal sys- } \\
\text { gical sys- } \\
\text { ctors/Ther- }\end{array}$ & $\begin{array}{l}\text { P-S = Psy } \\
\text { O = } \\
\text { munity/lnc } \\
\text { nal factors } \\
\text { Note } \\
N(1980 \text { - } \\
\text { N (1985 - }\end{array}$ & $\begin{array}{l}\text { cial factors } \\
\text { fog Com } \\
\text { Occupatio } \\
y \\
82 \\
77\end{array}$ \\
\hline
\end{tabular}

Table II shows a detailed analysis of the numbers of articles on particular topics published during the ten-year period under review (1980 to 1989). On comparing the two five-year periods, the greatest increase was in papers on education/administration ( $9 \%$ to $21 \%$ ), whereas the number of articles related to geriatric factors/therapy decreased markedly (11\% to $3 \%$ ), followed by those on paediatric factors/therapy (15\% to $10 \%)$.

\section{Trend in authorship (Table III)}

The findings of the ten-year survey indicate that there were significantly fewer authors with a Diploma in Physiotherapy (PT (Dip)) only ( $23 \%$ to $10 \%$ ) in the second five-year period, while there were similarly more authors with some postgraduate qualification $(11 \%$ to $16 \%)$ in the same period. The numbers of all physiotherapists with postgraduate qualifications, such as an Honour's or Master's degree or a Doctor of Philosophy, also increased (12\% to 22\% and $0 \%$ to $3 \%$ ). The number of medical doctors writing papers in this Journal during this period decreased (17\% to $12 \%$ ).
TABLE III: TREND IN AUTHORSHIP

\begin{tabular}{|c|c|c|c|c|}
\hline \multirow[t]{2}{*}{ Authorship } & \multicolumn{2}{|c|}{$1980-1984$} & \multicolumn{2}{|c|}{$1985-1989$} \\
\hline & $n$ & $\%$ & $n$ & $\%$ \\
\hline PT(Dip)I & 19 & 23 & 8 & 10 \\
\hline PT (B) & 18 & 22 & 16 & 21 \\
\hline $\mathrm{PT}+\mathrm{B}$ & 1 & 1 & 3 & 4 \\
\hline $\mathrm{PT}+\mathrm{H} / \mathrm{M}$ & 10 & 12 & 17 & 22 \\
\hline $\mathrm{PT}+\mathrm{PhD}$ & - & - & 2 & 3 \\
\hline MBBCh & 14 & 17 & 9 & 12 \\
\hline Grad & 4 & 50 & 1 & 1 \\
\hline Postgrad & 9 & 11 & 12 & 16 \\
\hline Non-deg & 5 & 6 & 3 & 4 \\
\hline NS & 2 & 2 & 6 & 8 \\
\hline $\begin{array}{l}\text { Key } \\
\text { PT (Dip) = Physiotherapy, } \\
\text { Diploma } \\
\text { PT (B) = Physiotherapy, Ba- } \\
\text { chelor's degree } \\
\text { PT + B = Physiotherapy plus } \\
\text { another Bachelor's degree }\end{array}$ & $\begin{array}{l}\text { PT }+\mathrm{H} / \mathrm{M} \\
\text { plus an Hon } \\
\text { gree } \\
\text { MBBCh = } \\
\text { Grad =: Am } \\
\text { Postgrad = } \\
\text { graduate }\end{array}$ & $\begin{array}{l}\text { siotherapy } \\
\text { lasters de- } \\
\text { I doctor } \\
\text { graduate } \\
\text { ther post- }\end{array}$ & $\begin{array}{l}\text { Nondeg } \\
\text { other diplo } \\
\text { NS = qual } \\
\text { lied } \\
\text { Note } \\
\text { N (1980 - } 1 \\
\text { N (1985 - 1 }\end{array}$ & $\begin{array}{l}\text { degree eg } \\
\text { not speci- } \\
\frac{82}{77}\end{array}$ \\
\hline
\end{tabular}

\section{DISCUSSION}

Although this survey reviews publications in the South African Journal of Physiotherapy over two relatively short periods of five years each (1980 to 1984 and 1985 to 1989), it does indicate general trends in current physiotherapy research in South Africa.

The majority of the papers ( $71 \%$ and $69 \%$ ) are still descriptive in nature, which suggests that many authors are not orientated towards scientifically-based research. The small number of clinical trials reported does not change much $(7 \%$ to $8 \%$ ) from one to the other five-year period. This may be due to the fact that clinicallybased research is notoriously difficult to carry out to completion. The decrease in surveys (15\% to $8 \%$ ) during these periods may be indicative of a waning interest, among researchers, in retrospective studies and reviews, or of the inherent difficulties of such research. The marked increase in experimental trials ( $7 \%$ to $16 \%$ ) suggests an increased awareness of the value and necessity of such trials in physiotherapy research among some researchers. However, the number of reports of such trials (11\% of the articles over ten years) is still extremely low when compared with the number of descriptive articles (70\% of all papers over ten years), and when compared with research trends in Canada (1973 to 1982$)^{2}$, where data-based research (reporting original data) increased from $33 \%$ to $45 \%$, and descriptive papers decreased from $45 \%$ to $25 \%$ during this time. Comparisons with other Western countries are not possible at present because of a lack of information about their current research trends.

The significant increase in the use of statistical analyses of data from the one five-year period to the other (6\% to $13 \%$ ) suggests that researchers are tending towards a more scientific approach to the analysis and interpretation of their results.

The marked increase in papers on education/administration between 1980 to 1984 and 1985 to 1989 (9\% to $21 \%$ ) confirms the suggestion, made in the report of an earlier survey of the South African Journal of Physiotherapy ${ }^{1}$, that there is generally interest in and concern for the standards of physiotherapy education and administration, which have a bearing on the image of the profession in South Africa. The increase in cardiopulmonary research ( $9 \%$ to $17 \%$ ) is indicative of a major research interest at present.

The decrease in the number of articles on geriatrics (11\% to $3 \%$ ), paediatrics (15\% to $10 \%$ ) and psycho-social factors ( $9 \%$ to $5 \%$ ) is surprising considering the widespread interest in community-based medicine and allied disciplines. This decrease may be due to the difficulties of human- or patient-based research in the field or clinical setting. The decrease in the number of papers on electrother- 
apy/equipment (9\% to 7\%) and on the applied basic sciences (7\% to $3 \%$ ) suggests a waning interest in these topics among researchers.

The finding in this survey that more authors (physiotherapists and other professionals) with postgraduate qualifications are publishing their research indicates an awareness of the need for scientific research, as was suggested in the earlier survey ${ }^{1}$. This increase also shows that more physiotherapists are obtaining higher qualifications which will equip them better for conducting such research.

\section{CONCLUSION}

This survey has shown some growth in South Africa in physiotherapy research. The studies under review reflected an awareness of the need, within the profession of physiotherapy, for higher scientific standards of research. However, these changes are not as yet enough to promote the profession of physiotherapy as an acknowledged science as well as an art.

\section{REFERENCES}

1. Mitchell J. Publication of our research: A journal survey. South African Joumal of Physiotherapy 1990;46(3):7-10

2. Dean E. Physiotherapy Canada survey (1973-1982): A trend to research. Physiotherapy Canada 1985;37(3):158-161.

\section{PHYSIOTHERAPISTS}

WORK IN THE UNITED STATES

We handle all Licensure and Visa paperwork.

Minimum commitment of one year required.

Write or phone collect:

THERAPY RESOURCE NETWORK

P O Box 5430355 N Main Street

Plymouth, MI 48170, USA

091 (313) 455-6660

\section{CAMBRIDGE COLLOCATION: EUROPEAN MEDICAL AND \\ PROFESSIONAL RECRUITMENT}

Physlotherapy vacancies In the UK: we have vacancles for physiotheraplsts in the private health sector in the UK. Excellent salarles and working conditlons.

Please contact: Maureen Johnston Brown or Margaret Lamb, Cambridge Collocation, 191 Huntlingdon Roed,

Cambrldge CB3 ODL, England.

Telephone: (0)223 276891

Fax: (0) 223276871

Employment Agencies Act 1973 Licence No SE 118181 VAT No 538357911

\section{PHYSIOTHERAPY DEPARTMENT}

Lecturers, Junior Lecturers (fulltime and part-time) as well as sessional lecturers and clinical instructors are needed to join in the challenging, stimulating and rewarding work of this department - in conjunction with the Physiotherapy Department of the Johannesburg Hospital. Lecturers will be expected to participate in management, planning, clinical work, research as well as teaching.

For further enquiries, contact Prof. M. Goodman, Department of Physiotherapy, Medical School, York Road, Parktown 2193, or phone (01 1) 488-3450/1.

\section{WITS UNIVERSITY}

The unlversity consistently opposes apartheld.

\section{Beheer Fisioterapeut}

\section{TYGERBERG-HOSPITAAL, PAROWVALLEI}

Besoldlging: Die minimum aanvangsalaris sal bereken word tussen R38 697 - R44 796 plus 'n 10\% niepensioendraende toelae per jaar.

Vereistes:

- Registrasie as Fisioterapeut by die SA Mediese en Tandheelkundige Raad.

- Ondervinding in die bestuur en administrasie van 'n fisioterapiedepartement.

- Deelname aan voortgesette fisioterapie-onderrigprogramme.

- Ondervinding van kliniese onderrig aan studente. Pllgte:

- Bestuur en administrasie van die Departement Fisioterapie, Tygerberg-Hospitaal (33 poste) in samewerking met die Hoof van Departement.

- Deelname aan kliniese onderrig en evaluering van studente.

- Reël van voortgesette onderrigprogramme vir fisioterapie-personeel.

- Indiensopleiding van fisioterapie-assistente.

- Demonstrasies aan ander groepe gesondheidswerkers met betrekking tot hantering van pasiënte.

- Bywoning van Kommissie vir Administrasie se Bestuurskursusse (indien nie alreeds voltooi nie).

Navrae:

Mej. S H Inwin-Carruthers, tel. (021) 931-1311 bylyn 300

Aansoeke moet gedoen word op die voorgeskrewe vorm $Z .83$ (by enige staatsdiensdepartement verkrygbaar) en gerig word aan die Direkteur-Generaal, Personeelbestuursdienste, Posbus 659, Kaapstad 8000 . Slultingsdatum: 30 November 1990. 